New Zealand journal of industrial relations, 1987, 12, 37-42

\title{
The ethnic origins of trade union secretaries
}

\author{
Paeder Ó Brosnacháin*
}

A political satirist recently wrote of the FOL Conference: "You are immediately conscious of the wide racial range of delegates represented. The predominant groupings appear to be Maori, Pakeha and Irish" (Welch, 1986, p. 13). This comment, if it is to be taken seriously, could hardly refer to persons of Irish birth. It could however be interpreted to mean persons of Irish ancestry. The role of Irish persons or persons of Irish descent in New Zealand unions has not been documented but in examining the names of the secretaries of registered unions of workers and employers for another purpose (Brosnan, Walsh and Rowe, 1985) we could not help but notice the plethora of Celtic names among the secretaries of workers unions and the relative dearth among the secretaries of employer unions. This is not the first such observation. Howard Elliott, the leader of the Protestant Political Association, complained in 1917 of "the preponderance of Irish names among delegates to the 1917 Labour Conference" (Davis, 1974).

Irish persons have been found to be predominant in unions in Australia and the USA. The role of the Irish in Australian unionism has not been documented fully - perhaps because the role of the Irish in Australia has been powerful at all levels. Nonetheless, O'Farrell's (1969) work has unearthed some, less than objective, writers' comments on the involvement of Irish in Australian unions. ". . few people did more work for unionism ... than the sons and grandsons of the Irish Catholic immigrants to Australia" (O'Farrell, p. 381) and "they are vigorously active in the trade unions in opposing anti-Christian forces" (O'Farrell, p. 397).

For the USA. Sowell (1983) notes the high proportion of Irish among union leaders and further reports that Irish Americans are seldom found in business. Doyle (1975) has found that while "Numerically, Irish Americans dominated few trades (except plumbers and team fitters), politically they dominated a majority of the unions of organized trades". Montgomery (1980) reports that, in the first decade of this century "Irish Americans occupied the presidencies of more than 50 of the 110 unions in the American Federation of Labour".

The facts of Irish American involvement in unions are little in doubt. The reasons for it are less clear. Writers such as Sowell (1983) rely on a theory of cultural determinism which links the behaviour of Irish migrants and subsequent generations to the culture of Ireland itself. Thus they choose to stress such things as a real or imagined talent for oratory, a tradition of rebellion against oppression and skill in building organisations (Blessing, 1980) - gained from the experiences in the Whiteboy movement or more likely in the Fenians.

Other writers offer more prosaic explanations. Fallows (1979), for example, provides an explanation largely in terms of the situation in which Irish migrants to America found themselves. They were predominantly working class, and condemned to the worst jobs. They could however speak English, had been in America longer than other migrants, and thus inevitably became the spokespeople for their work group in dealings with their Yankee bosses. The more ambitious could see employment as a union official providing upward mobility without requiring extensive education. A similar view is taken by Montgomery (1980).

Senior Lecturer, Industrial Relations Centre, Victoria University of Wellington.

Research assistance of Dean Hyslop is gratefully acknowledged. Bert Roth kindly commented on an earlier draft and provided the data on which Table 4 is based. 


\section{$38 \quad$ Paeder Ó'Brosnacháin}

Although he does focus on the links in the 1880 s between trade unionism and Irish organisations such as the Land League and the Fenian Brotherhood, he sees Irish involvement in unions, and the particular forms that it took, as determined more by the American class structure and the labour process itself than by any peculiarly Irish phenomena. He concludes that, despite Irish hegemony in a large number of unions, "a distinctively Irish imprint on the labor movement has become increasingly difficult to identify"

The involvement of Irish persons and their descendents in New Zealand is again a reflection of the fact that Irish immigrants to New Zealand were disproportionately represented among the working classes (Davis, 1974, passim; Gustafson, 1980, p. 125-6). Thus it was inevitable that they should be more strongly represented in unions than British migrants. The role of the Catholic Church is also undoubtedly important. Catholics were more inclined to migrate from Ireland and, among the Pakeha population, to be Irish and to be Catholic have been almost the same thing. Catholic teaching in contrast to that of many Protestant faiths has viewed trade unionism as legitimate. Although the Catholic Church looked askance at socialism, it felt more comfortable with trade unionism which it saw as similar to some of its own institutions (Rerum novarum, 1891). Certainly trade unionism was more in keeping with Catholicism than Protestant individualism (Mayor, 1967). Further, priests and Catholic schools used to encourage Catholics to be active in their union as a counter to "atheistic communism".

The link between the Church, New Zealand labour and Irish national issues was however a complicated, and far from easy relationship (Davis, 1974). The interaction between these issues resulted in close contact between Irish nationalists and the radical left. Thus Irishmen were prominent in the early New Zealand Communist Party and the Labour Party grew from a nucleus in the Grey Valley where the Irish were traditionally strong and Webb, Hickey and Semple, founders of the Red-Fed, each had Irish ancestry.

What then of the casual observations that persons with Irish ancestry are currently more active in unions? To test this observation, the following experiment was devised: the surnames of secretaries of registered unions were classified according to the primary country of origin of that name. A sample of 231 names $^{2}$ was drawn from the electoral rolls (General, plus Maori) and similarly classified. We then tested the null hypotheses that the proportion of names of each country of origin in the electoral rolls were the same as for union secretaries. The origin of the surname is of course an ambiguous indicator of cultural origin. Persons with an Irish surname may have little Irish ancestry and no Irish cultural inheritance. Conversely, a person with a non-Irish name could have predominantly Irish ancestry and a strong Irish cultural affiliation. It is expected here that the proportions of different surnames in a specific population correspond to the ancestry of the same proportion of that population. The statistical implications of this are not taken into account in the statistical tests reported below. Names were classified using 2 standard dictionaries of surnames (Cottle, 1978; Reany, 1970) and 8 classifications were used: Maori, English, Irish, Scottish, Welsh, Continental European. Pacific Island Polynesian plus Others and Unknowns. The resulting distributions are given in
Table 1 .

Table 1: Surnames by origin - secretaries of registered unions

\begin{tabular}{|c|c|c|c|c|c|c|c|c|c|}
\hline & Maori & English & Irish & Scottish & Welsh & $\begin{array}{l}\text { Continental } \\
\text { European }\end{array}$ & $\begin{array}{c}\text { Pacific } \\
\text { Island } \\
\text { Polynesian }\end{array}$ & $\begin{array}{c}\text { Others } \\
\text { plus } \\
\text { Unknown }\end{array}$ & Total \\
\hline \multicolumn{10}{|c|}{ Union Secretaries } \\
\hline $\begin{array}{l}\text { Number } \\
\text { Percentage }\end{array}$ & $\begin{array}{r}2 \\
1.0\end{array}$ & $\begin{array}{r}90 \\
46.9\end{array}$ & $\begin{array}{r}37 \\
19.3\end{array}$ & $\begin{array}{r}41 \\
21.4\end{array}$ & $\begin{array}{r}5 \\
2.6\end{array}$ & $\begin{array}{r}7 \\
3.6\end{array}$ & $\begin{array}{r}0 \\
0.0\end{array}$ & $\begin{array}{r}10 \\
5.2\end{array}$ & $\begin{array}{r}192 \\
100.0\end{array}$ \\
\hline \multicolumn{10}{|c|}{ Sample of Registered Voters } \\
\hline $\begin{array}{l}\text { Number } \\
\text { Percentage }\end{array}$ & $\begin{array}{r}8 \\
3.5\end{array}$ & $\begin{array}{r}117 \\
50.6\end{array}$ & $\begin{array}{r}14 \\
6.1\end{array}$ & $\begin{array}{r}37 \\
16.0\end{array}$ & $\begin{array}{r}14 \\
6.1\end{array}$ & $\begin{array}{r}11 \\
4.8\end{array}$ & $\begin{array}{r}5 \\
2.2\end{array}$ & $\begin{array}{r}25 \\
10.8\end{array}$ & $\begin{array}{r}231 \\
100.0\end{array}$ \\
\hline
\end{tabular}

1 The extent of the Catholic Church's concern about communists in trade unions appears not to be documented for the New Zealand case. O'Farrell (1969), however, documents it well for Australia. 2 The sample size was chosen so as to keep the standard error of the sample at, or below, 3 percent. 
The table reveals that the proportions of English and Continental European surnames were similar in the sample and among union secretaries. Welsh, Maori and Pacific Island Polynesian names are under-represented significantly $(\mathrm{p}<0.001)$. As we expected, Irish surnames are over-represented with a very high level of statistical significance $(\mathrm{p} \simeq 0.000)$. Scottish names are also over-represented among union secretaries although the level of significance is only marginal $(\mathrm{p}=0.04)$.

It was also clear, from the examination of the names of secretaries, that those with Irish surnames were more likely to hold the secretaryships of more than one union. In Table 2, the distribution of secretaryships is presented. A comparison of these data with Table 1 shows that, secretaries with Irish and Continental European surnames are more inclined to hold multiple secretaryships. The proportion of Irish rises from 19.3 percent to 24.2 percent and the proportion of European from 3.6 percent to 3.8 percent. If we repeat the statistical analysis on the data in Table 2, we find again that Welsh, Maori and Polynesian names are highly underrepresented among the holders of secretaryships $(\mathrm{p}<0.001)$ while Irish names are highly overrepresented $(p \sim 0.000)$. Scottish names among secretaryships a re no longer significantly overrepresented $(\mathrm{p}>0.05)$.

Table 2: Surnames by origin - secretaryships of registered unions

\begin{tabular}{|c|c|c|c|c|c|c|c|c|c|}
\hline & Maori & English & Irish & Scottish & Welsh & $\begin{array}{c}\text { Continental } \\
\text { European }\end{array}$ & $\begin{array}{c}\text { Pacific } \\
\text { Island } \\
\text { Polynesian }\end{array}$ & $\begin{array}{l}\text { Others } \\
\text { plus } \\
\text { Unknown }\end{array}$ & Total \\
\hline Number & 2 & 103 & 57 & 47 & 6 & 9 & 0 & 12 & 236 \\
\hline Percentage & 0.9 & 43.6 & 24.2 & 19.9 & 2.5 & 3.8 & 0.0 & 5.1 & 100.0 \\
\hline
\end{tabular}

Since the Irish entered the labour force "at the bottom" we might expect that the surfeit of Irish surnames would be mainly in the unions of unskilled workers while English surnames might be over-represented in the other categories. In order to test this proposition, the unions were classified into unskilled manual, skilled manual, and white collar and the exercise repeated for each. These results are presented in Table 3. It will be seen that the proportions of Irish names among secretaryships is highest for skilled manual unions but that the proportions for the other 2 categories are also significantly higher than we would expect $(\mathrm{p} \simeq$ 0.000 ). English surnames among the holders of secretaryships of white collar unions are consistent with the sample from the electoral rolles but there is a significant deficit of English names among secretaryships of unskilled $(\mathrm{p}<0.01)$ and skilled $(\mathrm{p}<0.05)$ manual unions.

Table 3: Surnames by origin - secretaryships by type of union

\begin{tabular}{|c|c|c|c|c|c|c|c|c|c|}
\hline Type of Union & Maori & English & Irish & Scottish & Welsh & $\begin{array}{l}\text { Continental } \\
\text { European }\end{array}$ & $\begin{array}{c}\text { Pacific } \\
\text { Island } \\
\text { Polynesian }\end{array}$ & $\begin{array}{l}\text { Others } \\
\text { plus } \\
\text { Unknown }\end{array}$ & Total \\
\hline \multicolumn{10}{|c|}{ Unskilled Manual } \\
\hline Number & 1 & 51.0 & 29 & 28 & 3 & 5 & 0 & 5 & 122 \\
\hline Percentage & 0.8 & 41.8 & 23.8 & 22.9 & 2.5 & 4.1 & 0 & 4.1 & 100 \\
\hline \multicolumn{10}{|c|}{ Skilled Manual } \\
\hline Number & 0 & 15 & 10 & 4 & 2 & 2 & 0 & 1 & 34 \\
\hline Percentage & 0.8 & 41.8 & 23.8 & 22.9 & 2.5 & 4.1 & 0 & 4.1 & 100 \\
\hline \multicolumn{10}{|c|}{ White Collar } \\
\hline Number & 1 & 37 & 18 & 15 & 1 & 2 & 0 & 6 & 80 \\
\hline Percentage & 1.3 & 46.3 & 22.5 & 18.8 & 1.2 & 2.5 & 0 & 7.5 & 100 \\
\hline
\end{tabular}




\section{Paeder Ó’Brosnacháin}

Montgomery (1980) whom we quoted above has determined that between a quarter and a fifth of persons "of eminence in the labour movement of the United States between the 1830s and 1870s" were Irish Americans. The concept "of eminence" is somewhat subjective but a comparable exercise for New Zealand is to examine the names of the presidents, vice presidents, secretaries and the executive members of the Federation of Labour for the 50 years of its existence. This exercise is reported in Table 4 and we find that while the proportion of Irish names is lower than Montgomery s for the USA, the figure of 11.4 percent is significantly more than the sample of electors $(\mathrm{p}<0.01)$.

Table 4: Surnames by origin - Federation of Labour executive members 1937-1986

\begin{tabular}{lrrrrrrrrr}
\hline & Maori & English & Irish & Scottish & Welsh & $\begin{array}{r}\text { Continental } \\
\text { European }\end{array}$ & $\begin{array}{c}\text { Pacific } \\
\text { Island } \\
\text { Polynesian }\end{array}$ & $\begin{array}{c}\text { Others } \\
\text { plus } \\
\text { Unknown }\end{array}$ \\
\hline $\begin{array}{l}\text { Number } \\
\text { Percentage }\end{array}$ & 0 & 22 & 5 & 6 & 3 & 3 & 0 & 5 & 44 \\
Total \\
\hline
\end{tabular}

The over-representation of persons of Irish descent among union secretaries would appear. on the basis of this exercise, to be substantiated. It could be objected however that the method was unnecessarily restrictive in that the allocation of names was based on the primary country of origin. Many English and Welsh names are found in Ireland and some Gaelic names are shared between Scotland and Ireland. Accordingly, we repeated the exercise using a wider definition of Irish names. The criterion adopted in this case was that the name be included in MacLysaght's Irish families (1957) and his More Irish families (1960). This wider definition gave 19.5 percent of registered voters and 28.1 percent of union secretaries as having Irish surnames and 33.0 percent of secretaryships as being held by persons with Irish surnames. The latter result is statistically very highly significant $(p \simeq 0.000)$. The disporportionate number of individuals with Irish names is less significant than when the narrower definition was used (in Table 1 ) but it is still highly significant $(\mathrm{p}<0.01)$. This wider definition increased the proportions in Table 3 to 34.4 percent, 41.2 percent and 28.8 percent for unskilled, skilled and white collar respectively (all very highly significant, $\mathrm{p}<0.001$ ). Applied to the data used to produce Table 4 , the number of possible Irish names increases from 5 to 17 or from 11.4 percent to 38.6 percent. Again the result is very highly significant $(\mathrm{p} \simeq$ $0.000)$.

Although Maori and Pacific Island Polynesian names are under-represented among union secretaries, they are also under-represented among employers. What of Irish names? Are they over-represented among employers too? Or is it, as Sowell (1983) claims, that persons of Irish descent are seldom involved in business? We have no data on employers as such but an analysis of the names of secretaries of registered employer unions, by individuals and by secretaryships, is presented in Table 5. When we compare these data with the sample of voters surnames presented in Table 1, we determine that Welsh, Maori and Polynesian names are significantly under-represented among secretaries $(\mathrm{p} \sim 0.000)$. Although there is a surplus of English. Scottish and European names and a deficit of Irish names compared to the sample of voters, the differences are not statistically significant at the 5 percent level. When we turn to the secretaryships, we find an over-representation of English, Irish, Scottish and European names. The shortfall of Welsh, Maori and Pacific Island Polynesian names is again very highly significant $(\mathrm{p} \simeq 0.000)$ and the over-representation of English and Irish names is significant at the 5 percent level. It should be noted however that the over-representation of Irish names among the holders of employer union secretaryships is entirely due to one individual with an Irish surname holding 15 secretaryships.

Welch's (1986) remark, with which we began this paper would appear to be half correct. That is, persons of Irish descent are a significant group among union leaders. Maori surnames though appear to be under-represented at the secretary level. It should be acknowledged that a high proportion of Maoris have non-Maori surnames. ${ }^{3}$ Nonetheless, if Maoris were equally represented among union secretaries, the proportion of Maori names should correspond with

This can be confirmed by an inspection of the Maori electoral rolls. 
Table 5: Surnames by origin - secretaries of employer unions

\begin{tabular}{|c|c|c|c|c|c|c|c|c|c|}
\hline & Maori & English & Irish & Scottish & Welsh & $\begin{array}{l}\text { Continental } \\
\text { European }\end{array}$ & $\begin{array}{c}\text { Pacific } \\
\text { Island } \\
\text { Polynesian }\end{array}$ & $\begin{array}{c}\text { Others } \\
\text { plus } \\
\text { Unknown }\end{array}$ & Total \\
\hline \multicolumn{10}{|l|}{ Secretaries } \\
\hline $\begin{array}{l}\text { Number } \\
\text { Percentage }\end{array}$ & $\begin{array}{r}0 \\
0.0\end{array}$ & $\begin{array}{r}86 \\
54.8\end{array}$ & $\begin{array}{r}9 \\
5.7\end{array}$ & $\begin{array}{r}31 \\
19.7\end{array}$ & $\begin{array}{r}3 \\
1.9\end{array}$ & $\begin{array}{r}9 \\
5.7\end{array}$ & $\begin{array}{r}0 \\
0.0\end{array}$ & $\begin{array}{r}19 \\
12.1\end{array}$ & $\begin{array}{r}157 \\
100.0\end{array}$ \\
\hline \multicolumn{10}{|c|}{ Secretaryships } \\
\hline $\begin{array}{l}\text { Number } \\
\text { Percentage }\end{array}$ & $\begin{array}{r}0 \\
0.0\end{array}$ & $\begin{array}{r}125 \\
56.3\end{array}$ & $\begin{array}{r}23 \\
10.4\end{array}$ & $\begin{array}{r}41 \\
18.5\end{array}$ & $\begin{array}{r}3 \\
1.4\end{array}$ & $\begin{array}{r}11 \\
5.0\end{array}$ & $\begin{array}{r}0 \\
0.0\end{array}$ & $\begin{array}{l}19 \\
8.6\end{array}$ & $\begin{array}{r}222 \\
100.0\end{array}$ \\
\hline
\end{tabular}

the proportions drawn in our sample. The other group which is under-represented is Pacific Island Polynesians. Their under-representation could even be understated since they may be under-represented among voters as well.

The under-representation of Maoris and Pacific Island Polynesians among union secretaries can be explained in terms of their migrant status, lower levels of education, alienation from Anglo Saxon institutions and the racism of Pakeha workers. The overrepresentation of persons of Irish descent is less easy to explain. In an earlier time, the Irish in New Zealand were little educated, and discriminated against by Protestant and Anglo Saxon employers (Davis, 1974). It could be though that their response was to become involved in the union movement. This would appear to have been the case in the USA. However, many of the arguments presented earlier in this paper with respect to the role of the Irish in American unionism do not translate easily to a New Zealand context. A further difficulty is to explain why, in the present era, when there is little or no discrimination against persons of Irish descent that they should continue to be heavily involved in unions. Societal attitudes are passed on from one generation to another but they are diluted over several generations unless they are reinforced by the surrounding culture. We indicated earlier that religion may be a factor. It would be interesting, where the data available, to examine whether union officials with Irish ancestry were more likely to be Catholics than other persons with Irish ancestry.

Sowell (1983) has made much of the idea that inter-ethnic group differences persist and claims that they "are real, large and enduring". At first sight these data might accord with such a view. However, Sowell's work has been attacked recently by Darity and Williams (1985). In an article mockingly called "Peddlers forever?", they point out that Sowell ignores the social class dimension and that many differences between ethnic groups are in fact differences between social classes. The predominance of persons of Irish ancestry among union officials is undoubtedly due to the former predominance of Irish among the working class. Although change is slow, the future may see fewer Irish and more Maori and Polynesian secretaries of unions.

\section{References}

Blessing, P J (1980) Irish. In Thernstrom, S (Ed) Harvard encyclopedia of American ethnic groups Belknop Press, Cambridge, Ma.

Brosnan, P, Rowe, P and Walsh, P (1985) Democracy and decision making in unions of employers New Zealand journal of business $7: 1-12$.

Cottle, B (1978) The Penguin dictionary of surnames Harmondsworth, Penguin Books.

Darity, W A and Williams, R M (1985) Peddlers forever? : Culture, competition, and discrimination American economic review 75 (2) : 256-261.

Davis, R P (1974) Irish issues in New Zealand politics Dunedin, University of Otago Press.

Doyle, D (1975) The Irish and American labour, 1880-1920 Saothar: Journal of the Irish + Labour history society 1 : 42-53. 


\section{Paeder Ó'Brosnacháin}

Fallows, M R (1979) Irish Americans Englewood Cliffs, Prentice Hall.

Gustafson, B (1980) Labour's path to political independence Auckland, Auckland University Press.

MacLysaght. E (1957) Irish families Dublin. Hodges Figgis and Co.

MacLysaght. E (1960) More Irish families Galway and Dublin. O'Gorman.

Mayor, S (1967) The churches and the labour movement London, Independent Press.

Montgomery, D (1980) The Irish and the American labour movement. In Doyle, D N and Edwards, O D (Ed) America and Ireland, 1776-1976 Wesport, Connecticut, Greenwood.

O'Farrell. P (1969) Documents in Australian Catholic history : Volume II : 1884-1968 London, Geoffrey Chapman.

Reany, P H (1970) A dictionary of British surnames London, Routledge and Kegan Paul Ltd. Rerum Novarum (1891) Encyclical Letter of Pope Leo XIII.

Sowell, T (1983) The economics and politics of race New York, William Morrow.

Welch. D (1986) Ministry in the pink New Zealand Listener 113 (2415) : 12-13 (31 May). 